\title{
Burton Sweet's Anniversary
}

At a special session of the Federal District court of northern Iowa, on June 21, at Waterloo, honor was paid to former congressman Burton E. Sweet of Waverly, by Judge H. N. Graven and other representatives of the court and bar of the district commemorating the 60th anniversary of Mr. Sweet's admission to the bar of the Federal court.

Four speakers heaped verbal laurels on the veteran attorney. They included Judge Henry N. Graven, of Greene; B. F. Swisher, Waterloo lawyer; Arben Young, Waverly attorney; and Lee McNeely, clerk of the Federal district court, of Dubuque.

Following these, it was Sweet himself who brought the assembled attorneys and their wives to the edges of their chairs. The 87-year-old lawyer then delivered an eloquent, thundering 20-minute address, at once patriotic and inspirational. He used all the courtroom techniques for which he is so well-known throughout Northeast Iowa. Sweet thundered and whispered, and paced back and forth; he gestured with both his hands and head.

"Our courts are the very bulwark of liberty-the foundation of freedom," he roared. "Banish the courts, and we'd be reduced to warring states," he declared. "Courts are the home of liberty, where freedom exists and rights are determined," Sweet continued.

"Without courts to construe it, the constitution itself becomes a worthless piece of paper . . A American jurisprudence is the most splendid in the world ...W We owe everything to our courts."

Turning then to an interpretation of "Americanism," Sweet declared: "Courts and jurisprudence are, in fact, our 'Americanism.' I think 'Americanism' is the grandest word in our language. It has been the goal of man since time began ... like a mighty river running through the centuries." He continued: "Courts are the conscience of this Nation."

Sweet noted the "grand and awfulness of current 
times" but expressed firm belief in the safe future of our country. "I say to you, there will always be a United States of America. I believe it's the will of the Infinite. Men who have tasted the sweets of liberty and freedom can never be subjected by Russia."

With another bit of eloquence seldom matched, Sweet then thanked his many friends present and those speaking at the special court session, saying: "Friendship is that gentle salutation of the heart that lives in all languages of men. It is a little less than love, a little more than comradeship."

Burton Sweet recalled that he had practiced law under all four judges of this Federal district court who have served since 1882, three of whom are now deceased, of whom "their lives are like a cloudless day, their memories like a sea at rest," he murmured.

A photostat of Mr. Sweet's original certificate of admission to the bar of the Federal court was presented by Lee McNeely, clerk of the court at Dubuque, and Judge Graven read into the record a resolution of congratulations to Sweet from the bar association of the Twelfth judicial district.

\section{Government by "Natural Aristocracy"}

It is an interesting fact which to some people seems ironical that Thomas Jefferson, traditionally regarded as the great protagonist of democracy, is also the man who gave us perhaps our most ringing declaration of faith in government by aristocracy. Jefferson was careful to explain that he meant a "natural" aristocracy, based on "virtue and talents," not on the accident of birth; but "The natural aristocracy," he continued, "I consider as the most precious gift of nature, for the instruction, the trusts, and government of society."

Note that Jefferson did not stop with committing government alone to the aristoi, that is to say "the best." He could have charged them also with education and fiduciary relationships, schools and guard- 
Copyright of Annals of Iowa is the property of State of Iowa, by \& through the State Historical Society of Iowa and its content may not be copied or emailed to multiple sites or posted to a listserv without the copyright holder's express written permission. However, users may print, download, or email articles for individual use. 